\title{
Impact of Music Played in an Automatic Milking System on Cows' Milk Yield and Behavior-A Pilot Study
}

\author{
Marie-Christine Lemcke, Asja Ebinghaus *(D) and Ute Knierim (D) \\ Farm Animal Behaviour and Husbandry Section, University of Kassel, Nordbahnhofstr. 1a, 37213 Witzenhausen, \\ Germany; mariechristine.lemcke@googlemail.com (M.-C.L.); uknierim@uni-kassel.de (U.K.) \\ * Correspondence: ebinghaus@uni-kassel.de; Tel.: +49-5542-98-1748
}

check for

updates

Citation: Lemcke, M.-C.; Ebinghaus, A.; Knierim, U. Impact of Music Played in an Automatic Milking System on Cows' Milk Yield and Behavior-A Pilot Study. Dairy 2021, 2, 73-78. https://doi.org/10.3390/ dairy2010007

Received: 4 December 2020

Accepted: 26 January 2021

Published: 1 February 2021

Publisher's Note: MDPI stays neutral with regard to jurisdictional claims in published maps and institutional affiliations.

Copyright: (c) 2021 by the authors. Licensee MDPI, Basel, Switzerland. This article is an open access article distributed under the terms and conditions of the Creative Commons Attribution (CC BY) license (https:/ / creativecommons.org/licenses/by/ $4.0 /)$.

\begin{abstract}
Practical experience suggests that music can have a positive effect on the welfare of dairy cows, which for some other animal species has been shown in earlier studies. Music could, furthermore, be a useful tool to support, for example, daily milking routines. In this pilot study we explored effects of music inside an automatic milking system (AMS) on cows' milk yield and behavior. The experiment was conducted on a Finnish dairy farm with 56 cows in loose housing. Over two 2-day periods without and with selected music pieces played inside the AMS, data on daily milk yield (DMY), selection gate passing frequency (GP), milking frequency (MF), and milking interval (MI) were recorded. For analyses, data of 17 Holstein-Friesian cows were used. At cow level, mean values over repeated measurements without and with music were calculated, and analyzed by paired t-tests (DMY, MF) or Wilcoxon tests (MI, GP). During intervals with music versus without, cows passed the selection gate more often (15.8 versus 13.8) and had higher MF (3.0 vs. 2.8). No differences were found in MI (07:49:21 vs. 08:37:38) and DMY (36.5 vs. 37.0). The latter might be explained by a ceiling effect. Overall, the results suggest that the investigated sample of cows perceived the selected music as attractive and that playing music might be a practical tool to reduce necessary efforts of driving cows to milking.
\end{abstract}

Keywords: dairy cows; music; automatic milking systems; milk yield; cow behavior; milking interval; milking frequency

\section{Introduction}

Dairy farmers' experiences presented in specialist press or public media, e.g., videos on youtube.com, suggest that cows are attracted by music and perceive listening to music as pleasant. There are numerous human research studies on the physiological, neurological, and psychological effects of music, some of which are also being investigated in individual animal species (review in [1]). In rodents, for example, it has been shown that music can reduce the immunosuppressive effect of stress [2]. Depending on the type of music, there were also indications of a stress-reducing effect, for example lower systolic blood pressure and higher dopamine levels in spontaneously hypertensive rats [3], lower adrenocorticotropic hormone and noradrenaline levels in mice [4], or a lower heterophile: lymphocyte ratio in layer hen chicks [5].

Similar effects could also occur in dairy cows and thus, playing music in the barn or milking parlor might increase cow welfare and productivity by reducing stress and residual milk. However, scientific research on the effects of music on cattle is sparse. Mainly associations between music and milk production were investigated, with ambiguous results: Evans and Albright ([6] cited from [7]) found no effect of rock music, but a significant increase of milk yield when classical music was played during milking. Higher milk yields when music was played were also noted by Moregaonkar et al. [8] with Indian instrumental music, by Liu et al. [9] with "light music" or "Mozart music", and by Zhao [10] with classical, pop, or rock music. In other studies with classical music, however, 
no significant changes in milk yield were found [11,12]. When playing rock music or African percussion music before milking, Donghai et al. [13] even recorded decreased milk yields. Also, North and MacKenzie [14] reported in the popular press that they had found lower milk yields when "fast" music had been played, while slightly higher milk yields had been associated with "slow" music of different genres. These partly contradictory findings appear to not only result from the use of different music genres, but might also be attributed to other characteristics of the chosen music, such as different frequencies (measured in hertz, $\mathrm{Hz}$ ), tempi (measured in beats per minute, bpm), or amplitudes (measured in deci-bel, dB). Cows are able to hear a frequency spectrum from $23 \mathrm{~Hz}$ to $35 \mathrm{kHz}$ [15] which includes part of the ultrasonic range from $16-35 \mathrm{kHz}$ [16]. Humans, as a comparison, can commonly perceive only up to $20 \mathrm{kHz}$ [17]. Amplitudes at or above $85 \mathrm{~dB}$ evoked behavioral [18-20] or physiological stress responses in cattle ([21] cited from [22]), indicating that the animals perceived the acoustic stimuli as aversive. The studies on music effects on cows cited above, however, did not report sound frequencies and only partly amplitudes and tempi: the music pieces used by North and MacKenzie [14] had less than 100 bpm; the "light music" and "Mozart music" used by Liu et al. [9] had less than $70 \mathrm{bpm}$ and were played at amplitudes of 60-75 dB. Moreover, previous investigations of music effects on cows' milk yield have been mainly conducted on farms with conventional milking parlors, where also confounding effects of the milkers' perception of the music may occur. On farms using automatic milking systems (AMS), however, this potential effect may be reduced, since here stockperson-cow interactions are reduced during the milking process [23].

With regard to effects of music on the cows' behavior, to our knowledge, only one investigation has been conducted yet: Uetake et al. [24] trained cows by conditioning to identify the start of milking in an AMS when they heard music being played in the barn and milking area. During the subsequent experimental period, changes between different behavioral states and the number of cows in the holding area increased significantly on days with music compared to control days without music. Since music had been played in the entire area of the barn, however, no conclusions on the attractiveness of music could be drawn.

If cows perceive music as attractive, the playing of this music during milking might be a practical tool to enhance productivity, particularly on farms using AMS, not only by reducing residual milk, but also by increasing cows' voluntary visits to the AMS. Thus, in the present experimental investigation we explored potential effects of playing selected, expectedly pleasant music inside the AMS on cows' milk yield as well as AMS visit frequencies and intervals.

\section{Materials and Methods}

\subsection{Farm and Animals}

The investigation was conducted from 21 March to 5 April 2019 on a Finnish commercial organic dairy farm keeping 56 cows of the Holstein-Friesian (60\%), Jersey $(38 \%)$ and Ayrshire (2\%) breed in a loose housing system.

Since 2009, the cows were milked in one AMS unit by DeLaval, managed by guided cow traffic: only cows with milking allowance (depending on the lactation status after 5, 6 , or $10 \mathrm{~h}$ with an expected milk amount of $\geq 8.0 \mathrm{~kg}$ ) could pass the selection gate from the feeding area to the AMS. Cows without milking allowance were guided to the lying area. Cows were fed with a total mixed ration containing grass silage, straw, crushed wheat, and protein pellets. Concentrates were additionally fed via two concentrate feeders and in the AMS. Cows before drying off were no longer given concentrates in the AMS. Routinely, no music had been played in the AMS or barn.

For analyses, data of cows were selected that fulfilled the following criteria: all test cows should be of the Holstein-Friesian breed, be in milk for more than 14 days, and receive concentrates in the AMS; they should not be in heat or lame and not have somatic cell counts $\geq 400,000$. This resulted in 17 selected test cows ( 7 primiparous and 10 multiparous cows) that were between 28 and 341 days in milk (mean \pm standard 
deviation $(\mathrm{SD})=182 \pm 80$ ) with daily milk yields ranging from 22.7 to $51.7 \mathrm{~kg}$ (mean $\pm \mathrm{SD}=36.8 \pm 8.9$ ) during the investigation period.

\subsection{Experimental Design}

The experiment took place over a total period of 16 days. The experimental design consisted of periods without music and periods with music being played inside the AMS The succession of a period without and with music was repeated once (Figure 1). Except for the first period without music, the first two days of each period served to habituate the cows; data of these days were not included into later statistical analyses. At the beginning of the second period with music, a technical failure of the AMS led to a stop of about $2 \mathrm{~h}$, resulting in delays in the milking process. To avoid any bias due to this, the data acquisition in this period was postponed by two days.

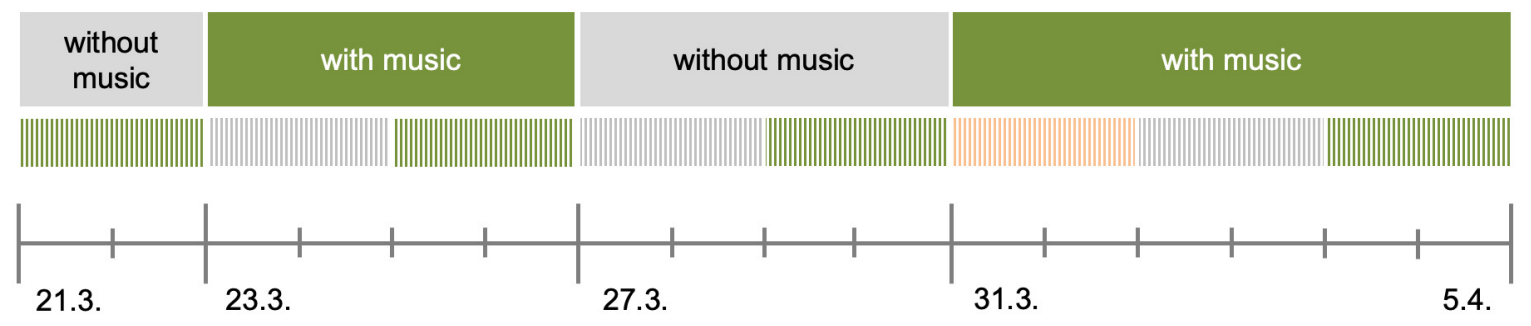

data acquisition for analyses

habituation

postponement after failure of the AMS

Figure 1. Experimental design-change between periods without and with music (AMS = automatic milking system).

The pieces of music were chosen based on the selection used in the "moosic study" by North and MacKenzie [14]. All selected pieces had a tempo of less than $100 \mathrm{bpm}$, but were of different genres: 57 pieces of popular music such as Blues (e.g., "What a difference a day makes" by Aretha Franklins) or Rock (e.g., "Everybody hurts" by REM), and 17 other pieces of classical music (e.g., Beethoven's Pastoral Symphony). The 74 pieces were combined into one playlist that included a total of six hours of music and were played continuously in random order over $48 \mathrm{~h}$. It was played alternately via a JBL Flip 3 Bluetooth speaker and an Anker Soundcore 2 speaker (in order to allow battery recharging). The speakers were each attached inside the AMS above the feeding trough.

Frequency and amplitude of the music inside the AMS were measured daily with a sound level meter (Lutron SL-4001). The measurements were taken at head height of the animals, during and between milkings. The frequencies ranged from $200 \mathrm{~Hz}$ to $16 \mathrm{kHz}$, with most values between $500 \mathrm{~Hz}$ and $10 \mathrm{kHz}$. The amplitude varied between 65 and $70 \mathrm{~dB}$, which corresponds to normal loud conversation. However, amplitudes of ambient noise changed during the milking process: at the beginning and end of a process amplitudes amounted to $80-85 \mathrm{~dB}$ with peaks up to $90 \mathrm{~dB}$; during milking, amplitudes ranged between 65 and $70 \mathrm{~dB}$. Throughout the milking process, but also during periods when no cow was being milked, the music was audible to humans inside the AMS, in the waiting area and at the selecting gate. Depending on the distance to the AMS, the music was hardly or no longer audible in the feeding and lying area.

Cow individual data on daily milk yield, passing frequencies at the selection gate, milking frequencies and intervals between milkings were provided by the AMS software.

\subsection{Statistical Analysis}

Data analyses were carried out using SPSS 24 . For all 17 test cows, mean values of all four dependent variables (daily milk yield, passing frequency at the selection gate, milking frequency, and milking interval) over the repeated measurements (a) with and (b) without music were calculated at individual animal level. Thus, two values per variable were available for each cow. For each variable normal distribution was visually tested via quantile-quantile diagrams. Because of the normal distribution of milk yield and milking 
frequency data, the differences between periods with and without music were analyzed by means of parametric tests (paired $t$-tests); frequencies of selection gate passings and milking intervals were analyzed by using non-parametric tests (paired sample Wilcoxon tests) due to non-normal distribution of data.

\section{Results}

Results of parametric and non-parametric tests are presented in Table 1. Daily milk yield did not significantly differ between periods with and without music. However, the frequency of selection gate passings and milking frequency were significantly higher during periods with music compared to periods without music. Subsequently, although not significantly, the milking intervals were 48 min shorter when music was played.

Table 1. Results of paired $t$-tests regarding milk yield and milking frequency, and results of paired Wilcoxon tests regarding selection gate passings and milking intervals, recorded during periods without and with music played inside the automatic milking system $(n=17)$.

\begin{tabular}{|c|c|c|c|c|}
\hline \multirow[b]{2}{*}{ Indicators } & \multirow{2}{*}{\multicolumn{2}{|c|}{ Periods without Music }} & \multicolumn{2}{|c|}{ Test Statistics } \\
\hline & & & $t$ & $p$ \\
\hline Milk yield $^{1}$ & $37.00 \pm 9.32$ & $36.55 \pm 9.00$ & 0.494 & 0.628 \\
\hline \multirow[t]{2}{*}{ Milking frequency $^{2}$} & $2.81 \pm 0.56$ & $3.03 \pm 0.52$ & -2.867 & 0.011 \\
\hline & \multicolumn{2}{|c|}{ median (min-max) } & $z$ & $p$ \\
\hline Gate passings ${ }^{3}$ & $13.75(5.25-21.5)$ & $15.75(10.75-24.25)$ & -3.174 & 0.002 \\
\hline Milking interval ${ }^{4}$ & $\begin{array}{c}08: 37: 38 \\
(06: 10: 25-12: 48: 37)\end{array}$ & $\begin{array}{c}07: 49: 21 \\
(05: 35: 04-10: 54: 59)\end{array}$ & -1.491 & 0.136 \\
\hline
\end{tabular}

\footnotetext{
${ }^{1} \mathrm{~kg} /$ cow $/ \mathrm{d},{ }^{2}$ number of milkings $/$ cow $/ \mathrm{d},{ }^{3}$ number of passings $/$ cow $/ \mathrm{d},{ }^{4}$ time between two milkings in h:min:s.
}

\section{Discussion and Conclusions}

For the present investigation, we played a music collection inside the AMS that we expected cows to perceive as pleasant. We were interested in whether playing this music would contribute to increased milk yields, more voluntary visits to the AMS, and thus shorter intervals between milkings. The tested sample of 17 dairy cows passed the selection gate significantly more often and were milked more frequently during the repeated 2-day periods with music compared to periods without music. This could be due to a mere activity stimulating effect of music as discussed by Uetake et al. [24]. Their study was carried out on a trial farm where the cows were milked twice a day at fixed times in the AMS, where they also received concentrate feed. In a preliminary phase, the cows were to learn to recognize the start of milking by music. For this purpose, music was played in the milking area and barn for $69 \mathrm{~d}$ at the beginning and throughout the milking period. After this conditioning phase, behavioral observations were carried out over a 20-day period at the afternoon milkings. It was found that on days with music, changes between different behavioral states (lying, standing, feeding) and the number of cows in the AMS holding area increased significantly compared to control days without music [24]. In our study, we neither undertook conditioning of the cows, nor was the music audible outside the milking area. Therefore, it is likely that the cows entered the milking area more often, because they were attracted by the music.

Our expectation of higher performance when music was played was based on two possible mechanisms. First, if the music would exert stress-reducing effects, amounts of residual milk might be decreased. Second, increased milking frequencies might stimulate milk production, although contradictory results on associations between milking frequency and milk yield are reported: Hamann and Halm [25] found an increase in milk yield by enhancing the milking frequency, but Gygax et al. [26] and Laurs et al. [27] found no associations. In our study, no increase in milk yield was found. The absence of an association might be attributed to the already high milk performance level of the investigated animals $(22.7-51.7 \mathrm{~kg} / \mathrm{cow} / \mathrm{d}($ mean $\pm \mathrm{SD}=36.8 \pm 8.9))$, possibly barely allowing for a further 
increase due to enhanced milking frequency (ceiling effect). Some of the earlier studies also found no ([6] cited from [7]; [11,12]) or even negative effects [13] of music on milk yields. One expectation was that in these previous investigations inappropriate tempi or amplitudes had been used, which were not perceived pleasant by the cows or did not have a calming effect. For the present experiment, the music was therefore selected according to criteria related to tempo (below $100 \mathrm{bpm}$ ) rather than related to genres, and played at moderate amplitudes $(65-70 \mathrm{~dB})$. At least, the overall results suggest that the cows did not perceive the selected music as aversive and, in contrast, that they were attracted to it. Playing an appropriate music selection in AMS might, therefore, contribute to an increase of cows' voluntary AMS visits and thus reduce the stockpersons' workload of driving individual cows to milking. Whether the present results were due to novelty aspects of the stimulation, to masking effects regarding technical noise in the AMS, or whether the cows perceived the music as pleasant, should be further investigated.

Author Contributions: Conceptualization: M.-C.L., A.E., U.K.; methodology: A.E., M.-C.L., U.K.; formal analysis: M.-C.L.; investigation: M.-C.L.; data curation: M.-C.L.; writing-original draft preparation: M.-C.L.; writing—review and editing: A.E., U.K.; visualization: A.E.; supervision: A.E., U.K. All authors have read and agreed to the published version of the manuscript.

Funding: This research received no external funding.

Institutional Review Board Statement: The study was performed in accordance with the "Guidelines for ethical treatment of animals in applied animal behavior and welfare research" [28]. Ethical review and approval were waived for this study, because no experimental handling of animals was involved. The cows were kept on a commercial farm in line with national law and guidelines.

Informed Consent Statement: Not applicable.

Data Availability Statement: The data presented in this study are available on request from the corresponding author.

Acknowledgments: Our special thanks go to the team of the dairy farm "Johannisbergs Gård" for their friendliness and cooperativeness.

Conflicts of Interest: The authors declare no conflict of interest.

\section{References}

1. Alworth, L.C.; Buerkle, S.C. The effects of music on animal physiology, behavior and welfare. Lab Anim. (N. Y.) 2013, 42, 54-61. [CrossRef]

2. Núñez, M.J.; Mañá, P.; Liñares, D.; Riveiro, M.P.; Balboa, J.; Suárez-Quintanilla, J.; Maracchi, M.; Méndez, M.R.; López, J.M.; Freire-Garabal, M. Music, immunity and cancer. Life Sci. 2002, 71, 1047-1057. [CrossRef]

3. Sutoo, D.; Akiyama, K. Music improves dopaminergic neurotransmission: Demonstration based on the effect of music on blood pressure regulation. Brain Res. 2004, 1016, 255-262. [CrossRef] [PubMed]

4. $\mathrm{Hu}, \mathrm{Y}$; $\mathrm{Xu}, \mathrm{L} . ;$ Yang, F.; Yang, P. The effects of enrichment with music or colorful light on the welfare of restrained mice. Lab. Anim. Comp. Med. 2007, 2, 71-76.

5. Dávila, S.G.; Campo, J.L.; Gil, M.G.; Prieto, M.T.; Torres, O. Effects of auditory and physical enrichment on 3 measurements of fear and stress (tonic immobility duration, heterophil to lymphocyte ratio, and fluctuating asymmetry) in several breeds of layer chicks. Poult. Sci. 2011, 90, 2459-2466. [CrossRef]

6. Evans, A.; Albright, J.L. The effects of music and noise upon behavior and milk production in dairy cows. In Proceedings of the 105th Annual Meeting of the Indiana Academy of Science, New Albany, IN, USA, 11 November 1989; Indiana Academy of Science, Indiana State Library: Indianapolis, IN, USA, 1989; p. 88.

7. Albright, J.L.; Arave, C.W. The Behaviour of Cattle; CAB International: Wallingford, UK, 1997; ISBN 0851991963.

8. Moregaonkar, S.D.; Bharkad, G.P.; Patil, A.D.; Markandeya, N.M. Effect of Indian instrumental music on milk production related factors in Deoni cows. Livest. Int. 2006, 10, 2-5.

9. Liu, J.; Xu, C.; Li, C.; Zhang, B.; Wang, Z.; Wang, C.; Yu, X. Effects of different types of music on lactation and antioxidant capacity of dairy cows. China Anim. Husb. Vet. Med. 2017, 44, 1388-1392. [CrossRef]

10. Zhao, X. Different Music on Milk Performance of Dairy Cows. Rev. Cient. Cienc. Vet. 2020, 30, 2126-2134.

11. Kıyıcı, J.M.; KoçyİgItt, R.; Tüzemen, N. The effect of classical music on milk production, milk components and milking characteristics of Holstein Friesian. J. Tekirdag Agric. Fac. 2013, 10, 74-81.

12. Li, C.; Liu, J.; Xu, C.; Yu, X. Effects of different types of music on lactation performance and protein metabolism of dairy cows. Acta Agric. Jiangxi 2017, 29, 82-85. 
13. Donghai, W.; Xiaoyan, M.; Yufei, W.; Chenglong, L.; Xiong, Y. Effects of Latin, Rock and African Percussion Music on Protein and Energy Metabolism in Cow. Meteorol. Environ. Res. 2018, 9, 87-90. [CrossRef]

14. North, A.; MacKenzie, L. "Moosic Study" Reveals Way of Increasing Milk Yields; University of Leicester, School of Psychology: Leicester, UK, 2001.

15. Heffner, R.S.; Heffner, H.E. Hearing in large mammals: Horses (Equus caballus) and cattle (Bos taurus). Behav. Neurosci. 1983, 97, 299-309. [CrossRef]

16. Heffner, H.E.; Heffner, R.S. Auditory Perception. In Farm Animals and the Environment; Phillips, C., Piggins, D., Eds.; CAB International: Wallingford, UK, 1992; pp. 159-184.

17. Purves, D.; Augustine, G.J.; Fitzpatrick, D.; Hall, W.C.; Lamantia, A.-S.; Mooney, R.D.; Platt, M.L.; White, L.E. The auditory system. In Neuroscience; Purves, D., Augustine, G.J., Fitzpatrick, D., Hall, W.C., Lamantia, A.-S., Mooney, R.D., Platt, M.L., White, L.E., Eds.; Oxford University Press: New York, NY, USA, 2019; pp. 265-286. ISBN 9781605358413.

18. Arnold, N.A.; Ng, K.T.; Jongman, E.C.; Hemsworth, P.H. The behavioural and physiological responses of dairy heifers to tape-recorded milking facility noise with and without a pre-treatment adaptation phase. Appl. Anim. Behav. Sci. 2007, 106, 13-25. [CrossRef]

19. Johns, J.; Masneuf, S.; Patt, A.; Hillmann, E. Regular Exposure to Cowbells Affects the Behavioral Reactivity to a Noise Stimulus in Dairy Cows. Front. Vet. Sci. 2017, 4, 153. [CrossRef] [PubMed]

20. Waynert, D.F.; Stookey, J.M.; Schwartzkopf-Genswein, K.S.; Watts, J.M.; Waltz, C.S. The response of beef cattle to noise during handling. Appl. Anim. Behav. Sci. 1999, 62, 27-42. [CrossRef]

21. Broucek, J.; Kovalcikova, M.; Kovalcik, K. The effect of noise on the biochemical characteristics of blood in dairy cows. Zivocisna Vyrob. 1983, 28, 261-267.

22. Brouček, J. Effect of noise on performance, stress, and behaviour of animals. Slovak J. Anim. Sci. 2014, 47, 111-123.

23. Jacobs, J.A.; Siegford, J.M. Invited review: The impact of automatic milking systems on dairy cow management, behavior, health, and welfare. J. Dairy Sci. 2012, 95, 2227-2247. [CrossRef] [PubMed]

24. Uetake, K.; Hurnik, J.F.; Johnson, L. Effect of music on voluntary approach of dairy cows to an automatic milking system. Appl. Anim. Behav. Sci. 1997, 53, 175-182. [CrossRef]

25. Hamann, J.; Halm, H. Influence of varying milking intervals on milk composition-A physiological approach on secretion of "normal milk". In Automatic Milking: A Better Understanding; Meijering, A., Hogeveen, H., de Koning, C.J.A.M., Eds.; Wageningen Academic Publishers: Wageningen, The Netherlands, 2004; pp. 215-220.

26. Gygax, L.; Neuffer, I.; Kaufmann, C.; Hauser, R.; Wechsler, B. Comparison of functional aspects in two automatic milking systems and auto-tandem milking parlors. J. Dairy Sci. 2007, 90, 4265-4274. [CrossRef] [PubMed]

27. Laurs, A.; Priekulis, J.; Zujs, V.; Salinšs, A. Milking frequency in milking robots with feed first cow traffic. In Proceedings of the 7th Conference, Engineering for Rural Development, Jelgava, Latvia, 29-30 May 2008; pp. 275-278.

28. International Society for Applied Ethology. Guidelines for Ethical Treatment of Animals in Applied Animal Behaviour and Welfare Research. 2017. Available online: https://www.applied-ethology.org/res/EthicalGuidelinesISAErevised2017\%20for\%20 council\%20meeting.pdf (accessed on 12 January 2021). 